\title{
PROCAINAMIDE THERAPY OF MALIGNANT HYPERTHERMIA: CASE REPORT
}

\author{
J. BREBNER, M.D., F.R.C.P.(c) AND J.A. JOZEFOWICZ, M.D. ${ }^{\circ}$
}

MALIGNANT HYPERTHERMIA has an overall mortality of 64 per cent. ${ }^{1}$ Its estimated incidence during anaesthetics is $1: 14,000$ in children and 1:40,000 in a mixed hospital population (occurrence predominantly in children). ${ }^{2}$ The most easily recognized type is that responding with rigidity instead of relaxation to the administration of succinylcholine. In a recent case report of this condition, pronounced rigidity followed an intubation dose of succinylcholine ( 20 seconds after administration). Inexplicably, a further dose of the relaxant was used later despite the claim of a rapid diagnosis of malignant hyperthermia, thus considerably aggravating the patient's situation.

Cases in which malignant hyperthermia has been recognized within ten minutes of onset of anaesthesia respond extremely well to treatment. ${ }^{1}$ In most such cases rigidity has occurred with the administration of succinylcholine and the anaesthetic has been immediately terminated. Therapy generally has consisted of correction of hyperthermia, of metabolic and respiratory acidosis, and of electrolyte changes. Those cases in which the diagnosis has not been made until over an hour after onset of anaesthesia have had a much worse prognosis. ${ }^{1}$

In the following report, immediate and follow-up therapy is described in the case of a patient developing malignant hyperthermia over the course of $1 \frac{1}{2}$ hours of operation. At that time the disease entity was fully recognized and treated.

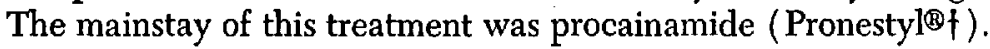

\section{Case Report}

A 40-year-old Italian male (G.F.) presented for vagotomy and pyloroplasty. He was a healthy, lean, muscular labourer who looked younger than his stated age. In the preoperative enquiry, he denied any family or personal history of adverse reactions to anaesthesia. In fact, he had one previous operation, a haemorrhoidectomy, in 1971. For this he had received general anaesthesia with an unknown agent (quite possibly halothane in this locale). In addition, he had no allergies and was taking no medication apart from the occasional use of antacid mixtures. Otherwise his past health and functional enquiry were negative. $\mathrm{He}$ denied any muscle disorders.

Physical examination was essentially normal and revealed a slightly dusky look-

\footnotetext{
-From Department of Anaesthesia, Faculty of Medicine, University of Toronto, and Toronto General Hospital.

†E.R. Squibb \& Sons Ltd.
} 
ing, slim, mesomorph in apparent good health. He weighed $69 \mathrm{~kg}$. Urinalysis was normal, as were haemoglobin (14.7), blood sugar (101), BUN (19), and WBC (5500). Blood pressure was $120 / 80 \mathrm{~mm} \mathrm{Hg}$, pulse 80 per minute and respirations were 20 per minute. His oral temperature at 0700 hours on the day of operation (19th of March) was $37^{\circ} \mathrm{C}$ and had been normal before that. He was a heavy smoker but had no overt signs or symptoms of chronic bronchitis.

Pre-operative medication consisted of Pantopon $20 \mathrm{mg}$ and scopolamine 0.4 $\mathrm{mg}$, given intramuscularly at 0700 hours. This produced good sedation and dryness of mouth. Following the establishment of an intravenous line at 0800 hours, anaesthesia was induced with the sequence: d-tubocurare $7 \mathrm{mg}$, thiopentone 250 $\mathrm{mg}$, atropine sulphate $0.2 \mathrm{mg}$ and succinylcholine $75 \mathrm{mg}$. This produced sleep and good relaxation without fasciculations.

After an easy intubation the patient was ventilated with nitrous oxide: oxygen (5:2 L/min) by an Air-Shields Ventimeter Ventilator with a tidal volume of 700 $\mathrm{ml}$ at a rate of 12 per minute. The airway pressure registered at $20 \mathrm{~cm} \mathrm{H}_{2} \mathrm{O}$. A semi-closed system was used with the absorber off (habit). When the patient started to show movement, $17 \mathrm{mg}$ of d-tubocurare was administered and produced further good relaxation.

During the course of the next $1 \frac{14}{4}$ hours, he was given a further $12 \mathrm{mg}$ of $\mathrm{d}$ tubocurare and $0.2 \mathrm{mg}$ of fentanyl, both in divided doses, in response to an increase in heart rate, rising blood pressure, and sweating. He had been monitored with an EKG from the start because the $P$ waves in the $V_{1-4}$ were biphasic and some of the $T$ waves were tall.

Approximately half an hour after the induction of anaesthesia, the surgeon commented that the blood looked a little dark. We adjusted the flow of gases to 4 litres of nitrous oxide and 2 litres of oxygen and no further comments were made. At this time G.F. was sweating and blood pressure and pulse were rising (Figure 1). One of us felt that the patient was warm but then so were we all. Since no thermistor was in the room, its use was forgotten until later. On that day, the hospital and the particular operating room we used, were warm, i.e. approximately $76^{\circ} \mathrm{F}$.

Subsequently the patient began to hiccup. At this stage his systolic blood pressure was $160 \mathrm{~mm} \mathrm{Hg}$ and pulse rate 110 per minute. Chlorpromazine $25 \mathrm{mg}$ given intravenously successfully stopped the hiccups but led to a drop in blood pressure to $80 \mathrm{~mm} \mathrm{Hg}$ systolic and an increase in heart rate to 180 per minute sinus rhythm. He was noted now to be obviously very hot, profusely sweating and cyanotic. The diagnosis of malignant hyperpyrexia was made and then confirmed by nasopharyngeal and rectal temperature readings of $39^{\circ} \mathrm{C}$.

\section{IMMEdiate MaNAGEMENT}

The surgeon was advised of the diagnosis and asked to terminate the operation as quickly as possible.

Nitrous oxide was shut off and the patient was ventilated immediately with 100 per cent oxygen at 10 litres per minute flow. He was given $100 \mathrm{mg}$ thiopen-

Roche. 


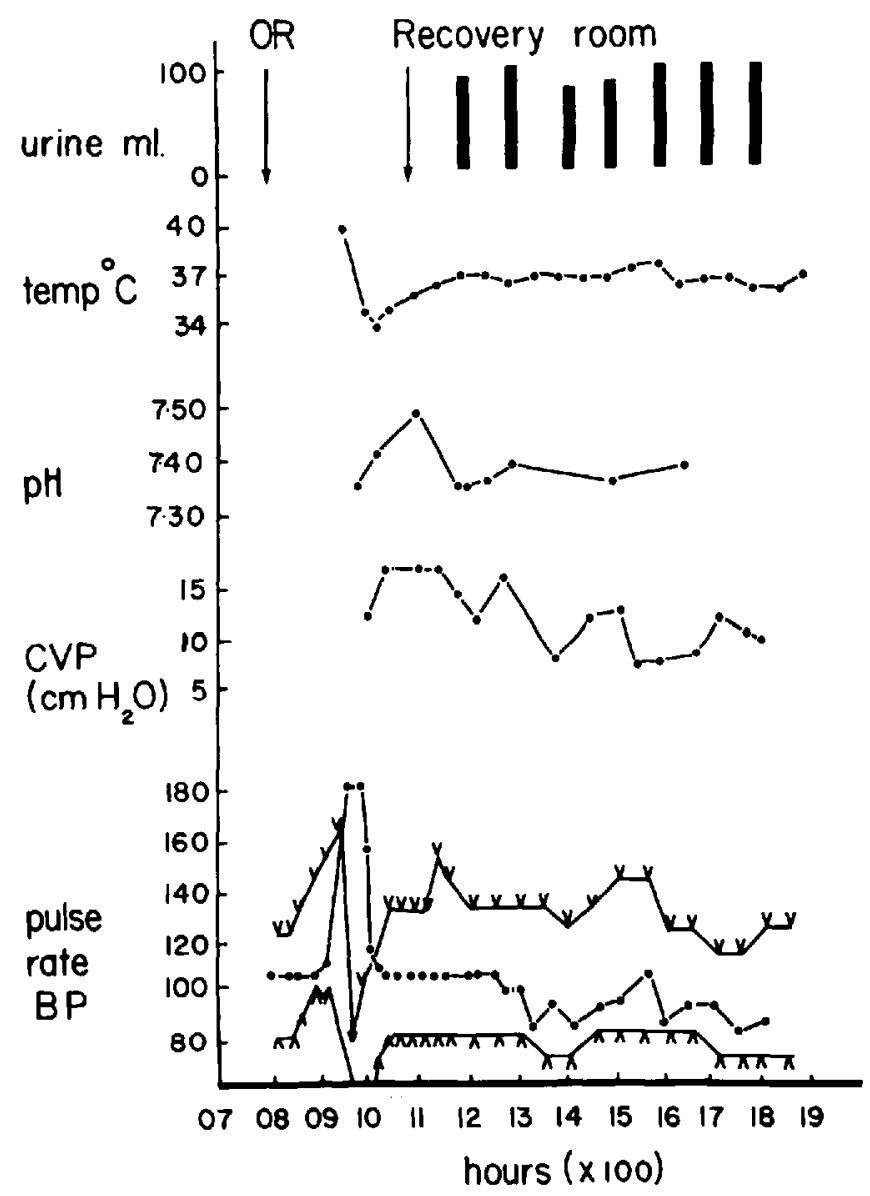

Ficure 1. Parameters noted during the operative and post-operative periods. Procainamide $900 \mathrm{mg}$ given intravenously between approximately 0940 and 1010 .

tone intravenously. Minute ventilation was set at 22 litres and almost immediately thereafter to 24 litres $(1200 \mathrm{ml} \times 20 / \mathrm{min})$. The absorber was left off deliberately because of the fear of halothane or methoxyflurane contamination of it. Since the vagotomy and pyloroplasty was just finished, the surgeon was able to close the abdomen rapidly (between 5 and 10 minutes).

The following therapeutic measures were undertaken: insertion of radial arterial catheter, urinary catheter, CVP line, intravenous infusion of cold lactated Ringer's solution, covering the body with crushed ice, administration of $90 \mathrm{mEq}$ $\mathrm{NaHCO}_{3}$ and administration of procainamide in $100 \mathrm{mg}$ boluses to a total of $900 \mathrm{mg}$ over half an hour. Extensive investigation of the patient was undertaken particularly during the first few critical hours (Table I).

\section{Results and Post-Operative Management}

The first change noted in the patient's condition was reduction of heart rate from 180 per minute to 120 per minute in fifteen minutes, following the administration of the sodium bicarbonate and approximately 500 to $600 \mathrm{mg}$ of procaina- 
BREBNER \& JOZEFOWICZ: PROCAINAMIDE THERAPY

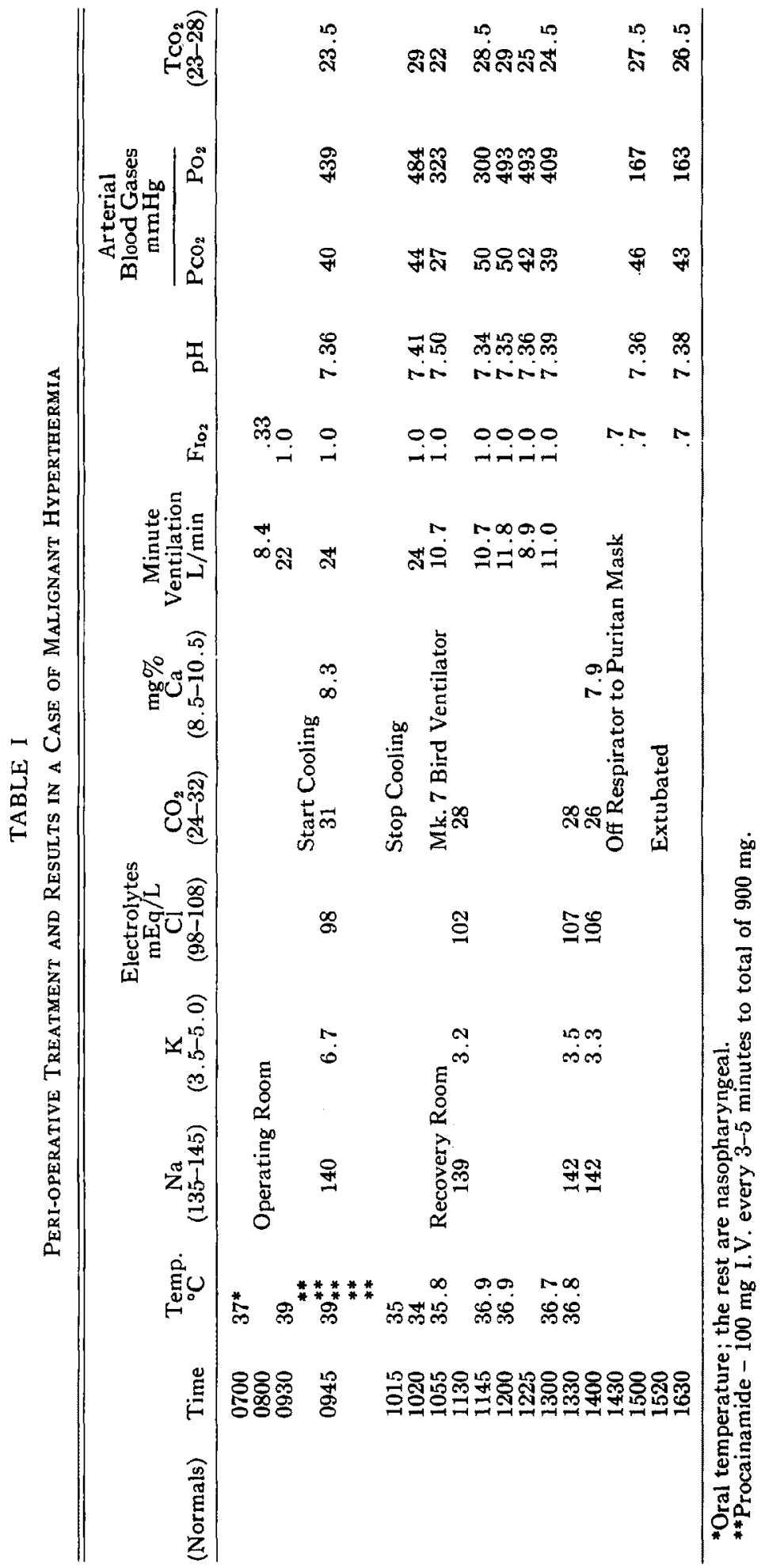


mide. The latter drug was discontinued when the heart rate settled to 100 per minute in sinus rhythm, which occurred at a total procainamide dose of $900 \mathrm{mg}$ (Figure 1). At no time was a dysrhythmia other than sinus tachycardia noted. During the course of the first half-hour the blood pressure came up steadily to $130 \mathrm{~mm} \mathrm{Hg}$ systolic.

As the heart rate approached 100 , it was noted suddenly that the naso-pharyngeal temperature had dropped to $35^{\circ} \mathrm{C}$. Ice was immediately removed from the patient's body, rectal cooling stopped, and room temperature intravenous solutions were started. Infusion of intravenous fluids was slowed drastically at this time since 2 litres had already run in and central venous pressure (CVP) was rising (Figure 1). The patient was covered with a blanket. His core temperature fell further to $34^{\circ} \mathrm{C}$ in the next fifteen minutes and then steadily rose back to $35.8^{\circ} \mathrm{C}$ by the time he arrived at the recovery room at 1055 hours (Figure 1).

As can be seen from Table I, the patient's serum $\mathrm{K}^{+}$was elevated to $6.7 \mathrm{mEq} / \mathrm{l}$ (normal: $3.5-5.0 \mathrm{mEq} / \mathrm{l}$ ), serum $\mathrm{Ca}^{++}$was 8.3 (normal: $8.5-10 \mathrm{mg} \%$ ), and CPK was 80 (normal: 40-60 units). To reduce serum potassium level, 20 units of regular insulin in $20 \mathrm{ml}$ of 50 per cent glucose in water was administered intravenously. The serum $\mathrm{K}^{+}$half an hour later was $3.2 \mathrm{mg} \%$ and thereafter slowly rose towards normal except for another slight dip at 1400 hours.

Because the patient was shivering and struggling against the respirator he was given two intravenous doses of diazepam $2.5 \mathrm{mg}, 15$ minutes apart. With this he settled and remained unconscious.

Since the insulin and glucose had been more effective than expected, blood sugar was determined at 1215 hours and found to be $50 \mathrm{mg} \%$. Twenty millilitres of 50 per cent glucose were infused into the patient which brought his blood sugar to $80 \mathrm{mg} \%$. A further $30 \mathrm{ml}$ of 50 per cent glucose were infused, which raised his blood sugar to $174 \mathrm{mg} \%$. He remained unconscious until approximately 1500 hours.

Vital signs were stable throughout the recovery room period of $7 \frac{1}{2}$ hours. Core temperature showed slight variation as can be seen in Figure 2. A cooling blanket was kept under the patient at all times but its use was not required in the recovery room. The patient was ventilated for four hours post-operatively and then extubated. He was given 70 per cent oxygen by a Puritan ${ }^{\oplus}$ mask and transferred to the Respiratory Failure Unit for further close monitoring. In the Respiratory Failure Unit, the policy of maintaining a cooling blanket under the patient was continued. During his stay there and subsequently serum creatine phosphokinase (CPK) was determined daily.

During the 24 hours after operation, the patient's temperature initially rose to 37.5 degrees $\mathrm{C}$ nasopharyngeal (38.5 rectal) at 2000 hours of the 19th and dropped as low as $35.0^{\circ} \mathrm{C}$ in response to cooling. The cooling was discontinued at 0800 hours on the 20th but resumed again for a further eight hours at 1130 hours on the same day. At 2300 hours cooling was discontinued entirely because the patient's temperature was considered to be stabilized.

On the 20th and 21st, he was complaining of generalized stiff muscles. The left shoulder seemed to be bothering him the most. Examination at this time suggested that his left thigh was smaller than his right. A later examination sug- 


\section{SERUM ENZYMES}

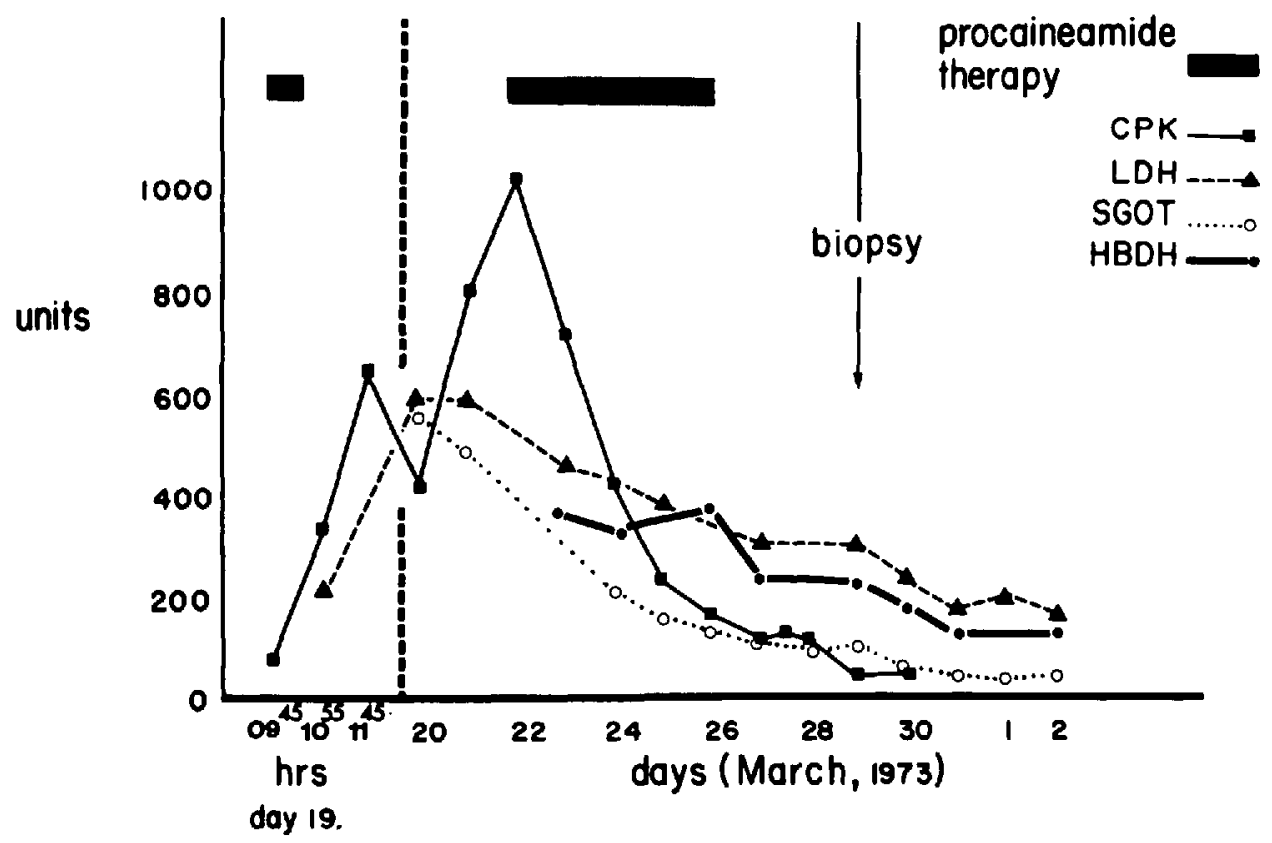

Figure 2. Serum enzyme studies performed during operation and post-operatively in our case of malignant hyperthermia.

gested that his thighs were the same size. The difference in size might have been due to swelling of the more affected muscle during the acute episode.

At this stage the CPK was steadily rising (Figure 2) and there were minor changes in the EKG (changes in axis). The increasing levels of muscle enzymes and the changing electrophysiological measurements of the heart suggested an on-going subclinical process. Thus, we decided that procainamide therapy should be restarted. Since no protocol existed for this procedure, it was decided to make use of the monitoring facilities of the Respiratory Failure Unit and to take the near middle range of therapy based on oral dosage suggested by the CPS. ${ }^{3}$

Procainamide drip infusion was started at $50 \mathrm{mg}$ per hour at 1400 hours on the 21st. It was continued until the 26th, at which time the CPK had fallen to 170 units from a high of 1040 units (Figure 2). Since the trend was good we discontinued the drip because we wanted to perform a muscle biopsy in another 48 hours, i.e. while the disease process was not completely cured but on the mend. Serum GOT (glutamic oxaloacetic transferase), LDH (lactic acid dehydrogenase), and HBDH (hydroxybutyric dehydrogenase) were followed, but not as closely as CPK. They can be seen to be quite elevated at a time that the serum CPK was back to normal. By the 29th, i.e. when the CPK was first normal, the patient seemed to be in very good clinical condition and quite mobile. The initial soreness and stiffness of muscles disappeared one day after restarting procainamide therapy. At no time was there myoglobin in his urine. The urine 
always appeared clear but did contain a trace amount of haemoglobin on the first three days of his illness. This may have been due to catheter irritation.

On the 29th, 48 hours after cessation of procainamide therapy, biopsy of the left deltoid muscle was performed under local anaesthesia by infiltration of the surrounding area with 2 per cent procaine $\mathrm{HCl}$. On this day the serum $\mathrm{CPK}$ was normal but SGOT, LDH, and HBDH were still elevated.

Caffeine contracture studies of the patient's muscle showed a normal pattern, as was seen by Kalow et al. ${ }^{4}$ in their one non-rigid malignant hyperthermia patient. Procainamide added to the wash chamber prior to repeat addition of halothane lowered the contracture tension developed by the muscle in response to caffeine. On April 2 electromyographic studies of the patient's muscles showed an abnormal pattern suggestive of myopathy. Neurological examination at this time was normal. Light microscopy showed some of the deltoid muscle fibers to be slightly larger than normal but the results from this and from electron microscopy were essentially inconclusive with respect to a specific myopathy.

\section{Discussion}

In retrospect, this patient had all the premonitory signs of developing malignant hyperthermia: dark blood noted by the surgeon, warm and sweaty skin, progressively rising pulse rate and blood pressure, and hiccups. ${ }^{1,5}$ of these, the earliest sign usually seen is tachycardia. ${ }^{1,6}$ We followed the common reaction of giving more drugs to correct for too-light anaesthesia. When drug therapy is not controlling these signs, one must seriously consider the possibility of malignant hyperthermia. In our case, unexplained cyanosis and nasopharyngeal temperature of $39^{\circ} \mathrm{C}$ (starting from $37^{\circ} \mathrm{C}$ ) clinched the working diagnosis. The early blood gases and electrolytes confirmed the diagnosis. That gross hyperventilation (1200 $\mathrm{ml} \times 20 / \mathrm{min}$ ) was required merely to maintain arterial $\mathrm{PCO}_{2}$ in a normal range (Table I) illustrates the tremendous respiratory acidosis brought about by activation of the Embden-Meyerhof pathway and the Kreb's citric acid cycle. ${ }^{b}$ Metabolic acidosis was little problem for us and perhaps it results from inadequate treatment at an early stage of the process. Hyperglycaemia, known to occur in this disease, ${ }^{6}$ prompted us to use an excessive proportion of insulin to glucose to treat the hyperkalaemia. Our experience suggests that early procainamide therapy prevents marked hyperglycaemia.

One of the factors responsible for delay in our diagnosis was the warmth of the operating room $\left(76^{\circ} \mathrm{F}\right)$. It may be helpful to others to bear in mind that the anaesthetized patient does not become hyperthermic if the ambient temperature is less than $78^{\circ} \mathrm{F} .^{7}$

The rapid shifts in serum $\mathrm{K}^{+}, \mathrm{Ca}^{+}+, \mathrm{CPK}$ and $\mathrm{LDH}$ reflect the leakiness of muscle membranes occurring with activation of the malignant fever syndrome. Previous evidence suggested that the rise in serum CPK was a relatively late development (days). ${ }^{1}$ Here we have seen that a very rapid rise of CPK can occur which continues over several days. From the data in Figure 2, it appears that procainamide effectively seals the muscle cell membranes, judging by the rapid fall in CPK level following its use. This suggests to us that procainamide 
may be the drug of choice in the treatment of both types of malignant hyperthermia, despite suggestions to the contrary. ${ }^{6}$ Furthermore, we feel that continuous therapy with the drug should be maintained until CPK and other enzyme levels are showing a distinct downward trend and approaching their normal levels in serum. In our patient, significant myoglobin release into the urine and consequent possibility of damage to the kidneys was prevented. In the past, when procainamide has been used to treat the disease, there have been many other drugs used as well. A dramatic drop of temperature has been reported after the use of procainamide when other drugs had failed. ${ }^{8}$ Polypharmacy may aggravate the disease, particularly when chlorpromazine is being used. ${ }^{9}$ On the other hand chlorpromazine has been advocated to assist cooling in malignant hyperpyrexia. ${ }^{10}$ In our case, chlorpromazine probably helped in the rapid cooling of our patient.

In the acute situation, procaine is useful since it is often more readily available. Because of its hydrolysis by serum cholinesterase ${ }^{11}$ procaine's duration of action is not as long as that of its amide derivative and so more will probably have to be used in the long run. Whichever drug is used, the dosage should be generous, e.g. 50-100 mg boluses till the dysrhythmia is brought under control. Naturally, this must be done with EKG monitoring.

In our patient we aimed for and achieved reduction of heart rate to 100 per minute. We were fortunate in not having to control ventricular arrhythmias which seem to occur commonly in this disease, particularly at late stages.,12 Possibly they would have appeared had we not reacted in time. Since time is a critical factor in treatment of the acute episode, we favour the use of the bolus effect to achieve rapid high levels of procainamide inside the cell. Correction of serum $\mathrm{pH}$ towards normal with $\mathrm{NaHCO}_{3}$ and hyperventilation will favour penetrance of the procainamide into the cell. The acidotic cell will then retain the ionized form of procainamide (or procaine) within it to achieve a high concentration at its site of action, which is most likely the sarcoplasmic reticulum. .,13,14 $^{-14}$

The slow onset of fever, lack of rigidity despite the use of succinylcholine, and normal caffeine contracture studies suggest that our patient's disease is of the non-rigid type. A rigid response to succinylcholine may have been aborted by the prior use of curare as has been seen in pigs. ${ }^{13}$ Complaints of skeletal muscle soreness or stiffness following the episode, so far, has been reported as occurring only in those with the rigid type of the disease. ${ }^{1}$ However, this patient complained of stiffness for a few days following his operation. Elevated muscle enzyme levels in serum have also been reported as occurring almost exclusively in rigid type patients. ${ }^{1}$ Thus there is a lot of evidence to suggest that our patient may have had the rigid type of malignant hyperthermia or a combination of rigid and non-rigid types of the disease.

The prime evidence we have that our patient does not have the rigid form of malignant hyperthermia is the result of the caffeine contracture study. The muscle of the non-rigid patients reacts like normal muscle on exposure to halothane and caffeine, and on exposure to succinylcholine and caffeine. ${ }^{4}$ The rigid type's muscle reacts to these agents with abnormally strong contracture. ${ }^{4}$ Procaine 
(and thus procainamide) would be expected to abort the contracture response to appropriate stress. ${ }^{13,14,15}$ There is a suggestion that this is true in these initial studies of this subject's muscle. We feel that it is highly unlikely that significant levels of procainamide were still present in the muscle at the time of muscle biopsy. The variable half life of procainamide in serum is between 2.5-4.7 hours (mean 3.7 hours), ${ }^{16}$ and our patient had not received the drug for 48 hours when the muscle samples were taken. Since this is over 10 half lives there should have been none, or virtually none, of the drug left in the body to affect the contracture studies.

We are assuming, on present evidence, that our patient had the non-rigid type of malignant hyperthermia. We feel that, despite suggestions to the contrary for non-rigid patients, all patients with malignant hyperthermia should first have a trial of therapy with heroic doses of procainamide (or procaine) in conjunction with cooling, massive hyperventilation (of the order of $20 \mathrm{ml} / \mathrm{kg} \times 16-20 / \mathrm{min}$ for adults), and bicarbonate or T.H.A.M. therapy. We are not against the use of chlorpromazine to help in cooling and sedation and it may be of help in the control of shivering. Diazepam was helpful in sedating the patient so that hyperventilation could be continued as long as necessary (in this case for about four hours).

\section{SUMMARY}

A 40-year-old Italian male of lean muscular physique developed malignant hyperthermia over the course of $1 \frac{1}{2}$ hours during an operation for vagotomy and pyloroplasty. Pre-operative medication was Pantopon ${ }^{\circledR}$ and scopolamine. During operation he received thiopentone, succinylcholine, atropine, $\mathrm{N}_{2} \mathrm{O} / \mathrm{O}_{2}$, d-Tubocurare, and fentanyl. Only thiopentone, $\mathrm{N}_{2} \mathrm{O}$, and fentanyl have been declared safe for use in a patient with malignant hyperthermia. Chlorpromazine was given just prior to making the diagnosis and may have helped in the rapid cooling that was achieved. The mainstay of therapy in the acute situation and in the postoperative period of one week was procainamide. The patient had a rapid recovery which was accurately reflected by his serum CPK levels. We advocate continuous administration of procainamide from the time of diagnosis of malignant hyperthermia until the CPK levels are near to normal again.

\section{RÉSUMÉ}

Un vieil italien de 40 ans, au physique maigre, a présenté de l'hyperthermie maligne durant une opération d'une demi heure pour vagotomie et pyloroplastie. En prémédication, il avait reçu pantopon ${ }^{\circledR}$ et scopolamine. Durant l'opération, il avait reçu du thiopentone, de la succinylcholine, de l'atropine et du $\mathrm{N}_{2} \mathrm{O}+\mathrm{O}_{2}$, du curare et du fentanyl. Seulement le thiopentone, le $\mathrm{N}_{2} \mathrm{O}$ et le fentanyl sont reconnus de toute sécurité chez les candidats à hyperthermie maligne. La chlorpromazine a été donnée au malade immédiatement avant de faire le diagnositic et cela a pu aider au refroidissement rapide qui a été fait. L'élément principal de la thérapie de cette situation d'urgence au cours de la période post-opératoire 
d'une semaine a été la procaïneamide. Le malade a récupéré rapidement et cela a été suivi par les taux de C P K sériques. Nous préconisons l'administration continuelle de procaïneamide dès le diagnostic de l'hyperthermie maligne jusqu'à ce que les taux de $\mathrm{C} \mathrm{P} \mathrm{K}$ reviennent près de la normale.

\section{ACKNOWLEDGMENTS}

We wish to express our appreciation to Drs. R.A. Gordon, W. Kalow, and B.A. Britt, who have done so much to encourage our awareness of malignant hyperthermia and its treatment. We hope our success here in some way repays their efforts.

Our thanks are extended to Dr. J.E.M. Young, resident surgeon, whose prompt responses were absolutely essential to the survival of our mutual patient.

We are grateful for the laboratory studies provided by Mrs. Mary E. Terreau, Dr. J.G. Humphrey's group, and finally to our own laboratories for carrying out the expensive daily CPK studies necessary for treatment.

\section{REFERENCES}

1. BRrtr, B.A. \& Kalow, W. Malignant hyperthermia: a statistical review. Can. Anaes. Soc. J. 17: 293 (1970).

2. Snow, J.C., Healy, G.B., \& Vaughan, C.W. Malignant hyperthermia during anaesthesia for adenoidectomy. Arch. Otolaryng. 95: 442 (1972).

3. Rotenberg, G.N. \& Hughes, F.N. Compendium of pharmaceuticals and specialties (Canada), 7th edition, Toronto: The Canadian Pharmaceutical Association, Inc. (1972).

4. Kalow, W., Brit, B.A., Terreau, M.E., \& Haist, C. Metabolic error of muscle metabolism after recovery from malignant hyperthermia. Lancet 2: 895 (1970).

5. Katz, D. Recurrent malignant hyperpyrexia during anesthesia. Anes. Analg. Curr. Res. 49: 225 (1970).

6. Britr, B.A. Recent advances in malignant hyperthermia. Anesth. Analg. Curr. Res. 51: 841 (1972).

7. Ryan, J.F. In Discussion 7 of International Symposium on Malignant Hyperthermia. Springfield: Thomas (1973), p. 466.

8. Beldaus, J., Small, V., Cooper, D.A., \& Britt, B.A. Post-operative malignant hyperthermia: a case report. Can. Anaes. Soc. J. 18: 202 (1971).

9. Pollock, R.A. In Discussion 7 of International Symposium on Malignant Hyperthermia. Springfield: Thomas (1973), p. 466.

10. Ryan, J.F. The early treatment of malignant hyperthermia. International Symposium on Malignant Hyperthermia. Springfield: Thomas (1973), p. 430.

11. KaLow, W. Hydrolysis of local anesthetics by human serum cholinesterase. J. Pharmacol. Exp. Ther. 104: 122 (1952).

12. Jones, E.W., Kerr, D.D., \& Nelson, T.E. Malignant hyperthermia - Observations in Poland China pigs. International Symposium on Malignant Hyperthermia. Springfield: Thomas (1973), p. 198.

13. Harrison, G.G. The effect of procaine and curare on the initiation of anaesthetic - induced malignant hyperpyrexia. International Symposium on Malignant Hyperthermia. Springfield: Thomas (1973), p. 271.

14. HarRison, G.G. Anaesthetic - induced malignant hyperpyrexia: a suggested method of treatment. Brit. Med. J. 3: 454 (1971).

15. Thorpe, W. \& SEEMAN, P. Drug-induced contracture of muscle. International Symposium on Malignant Hyperthermia. Springfield: Thomas (1973), p. 152.

16. Koch-WeSER, J. Pharmacokinetics of procainamide in man, Ann. N.Y. Acad. Sci. 179: 370 (1971). 